\title{
Replacement of soybean meal by soybean in multiple supplements for beef heifers grazing Urochloa decumbens during the dry season
}

\author{
Substituição do farelo de soja por grão de soja em suplementos \\ múltiplos para novilhas de corte em pastagens de Urochloa \\ decumbens durante o período da seca
}

\author{
Daniel Mageste de Almeida ${ }^{1 *}$; Mário Fonseca Paulino²; Marcos Inácio Marcondes ${ }^{2}$; \\ Luciana Navajas Rennó2; Lívia Vieira de Barros $^{3}$; Leandro Soares Martins ${ }^{4}$; \\ Faider Alberto Castaño Villadiego ${ }^{5}$; Sidnei Antônio Lopes ${ }^{4}$; David Contreras Marquez; \\ Aline Gomes da Silva ${ }^{4}$; Roman Maza Ortega ${ }^{4}$; Javier Enrique Garces Cardenas ${ }^{4}$
}

\begin{abstract}
This study aimed to evaluate the effect of replacing soybean meal with soybean in multiple supplements on nutritional parameters, microbial efficiency and productive of heifers grazing in Urochloa decumbens during the drought period. Were used 39 crossbred heifers of initial age and initial weight of 21 months and $309.5 \pm 7 \mathrm{~kg}$, respectively. The experimental design was completely randomized with four treatments with eight replicates, and a control treatment with seven replications. Two treatments had soybean meal as the protein source and two treatments had soybean as the protein source, containing $25 \%$ and $40 \%$ crude protein. The amount of supplement offered was $1.0 \mathrm{~kg} / \mathrm{animal} / \mathrm{day}$. The animals of the control group received only mineral salt ad libitum. The supplemented animals had higher average daily gain $(\mathrm{ADG})$ than control animals $(\mathrm{P}<0.10)$, and there was no difference in ADG among the supplements $(\mathrm{P}>0.10)$. There was an effect of supplementation $(\mathrm{P}<0.10)$ on intake of dry matter $(\mathrm{DM})$, organic matter $(\mathrm{OM})$, crude protein $(\mathrm{CP})$, ether extract (EE), non-fiber carbohydrates (NFC), total digestible nutrients (TDN) and neutral detergent fiber corrected for ash and protein (NDF). There were no differences $(\mathrm{P}>0.10)$ on intake of $\mathrm{OM}$ and $\mathrm{DM}$ grazing between the supplemented and nonsupplemented. Supplementation improved DM digestibility and all constituents of the $\operatorname{diet}(\mathrm{P}<0.10)$. It was found that the provision of multiple supplements optimises the performance of heifers grazing during the dry season, and that the substitution of soybean meal by soybean does not change productive performance of animals.
\end{abstract}

Key words: Dry, soybean, supplementation

\footnotetext{
${ }^{1}$ Discente do Curso de Doutorado do Programa de Pós-graduação em Zootecnia, Universidade Federal de Viçosa, UFV, Viçosa, MG, Brasil. E-mail: danielmagestedealmeida@hotmail.com

2 Profs. Drs., UFV, Viçosa, MG, Brasil. E-mail: mpaulino@ufv.br, marcos.marcondes@ufv.br; lucianarenno@ufv.br

${ }^{3}$ Prof $^{\mathrm{a}}$, Dr ${ }^{\mathrm{a}}$, Universidade Federal de Mato Grosso, UFMT, campus Cuiabá. Cuiabá, MT, Brasil. E-mail: liviavieiradebarros@ gmail.com

${ }^{4}$ Discentes do Curso de Doutorado do Programa de Pós-graduação em Zootecnia, UFV, Viçosa, MG, Brasil. E-mail: leandros_ martins@yahoo.com.br; sidneyufv@hotmail.com; davidestebas@hotmail.com; roman.ortega@ufv.br; alinegomesdasilva@ rocketmail.com.br; yojavier1@hotmail.com

5 Discente do Curso de Doutorado do Programa de Pós-graduação em Medicina Veterinária, Universidade Federal de Viçosa, UFV, Viçosa, MG, Brasil. E-mail: faider_cas@hotmail.com

* Author for correspondence
} 


\title{
Resumo
}

\begin{abstract}
Objetivou-se avaliar o efeito da substituição do farelo de soja pelo grão de soja sobre parâmetros nutricionais, eficiência de síntese microbiana e desempenho produtivo de novilhas Nelore sob pastejo em Urochloa decumbens durante o período da seca.Foram utilizadas 39 novilhas, com idade média inicial de 21 meses e peso médio inicial de $309,5 \pm 7 \mathrm{~kg}$. O delineamento experimental foi o inteiramente casualizado, com quatro tratamentos com oito repetições, e o tratamento controle com sete repetições. Dois tratamentos tinham como fonte proteica o farelo de soja, e dois tratamentos tinham como fonte proteica o grão de sojain natura, contendo $25 \%$ e $40 \%$ de proteína bruta na MS. Ofertou-se $1 \mathrm{~kg} \mathrm{MS} \mathrm{dia}{ }^{-1}$ de suplemento por animal. Os animais do grupo controle receberam apenas mistura mineral ad libitum. Os animais suplementados apresentaram GMD superior aos animais não suplementados $(\mathrm{P}<0,10)$, e não houve diferença de GMD entre os suplementados $(\mathrm{P}<0,10)$. Foi verificado efeito positivo da suplementação $(\mathrm{P}<0,10)$ sobre o consumo de matéria seca $(\mathrm{MS})$, matéria orgânica $(\mathrm{MO})$, proteína bruta (PB), extrato etéreo (EE), carboidratos não fibrosos (CNF), nutrientes digestíveis totais (NDT) e fibra em detergente neutro corrigida para cinzas e proteína (FDNcp). Não houve diferenças $(\mathrm{P}<0,10)$ no consumo de $\mathrm{MO}$ e MS de pasto entre os suplementados e os não suplementados. A suplementação melhorou a digestibilidade da MS e de todos os constituintes da dieta $(\mathrm{P}<0,10)$. Conclui-se que o fornecimento de suplemento múltiplo otimiza o desempenho de novilhas em pastejo no período da seca, e que a substituição do farelo de soja pelo grão de soja não altera o desempenho produtivo dos animais.
\end{abstract}

Palavras-chave: Grão de soja, seca, suplementação

\section{Introduction}

Cattle farming in Brazil is predominantly based in pastures, and is the most economic source of nutrients for ruminants in the tropics. Due to the recognised seasonality of the qualitative and quantitative production of the tropical forages, defining strategies for grazing management based on the conditions of the pasture must establish targets of management for each season of the year; this is because the morphological differentiation must be minimised in the dry season and coexist with the senescence (PAULINO et al., 2008).

Today, the supplementation of bovines in grazing is the alternative that has grown the most as a strategy to increase the productivity more than 2000\% between 1991 and 2006 (ANUALPEC, 2007). The optimisation of the use of forages and the weight gain of animals with the strategic use of multiple supplementation allows a better exploitation of the productive resources. The use of supplementation for animals in grazing constitutes a practice that may be adopted in the strategy of the management of pastures aiming to increase the capacity of support and the animal performance. For this, firm knowledge about the issue is necessary, with the intention of aiming for maximum technical and reproductive efficiency.

In ruminants, the grains do not constitute basal nutritional resources, but catalysts of the microbial growth in the search of the forage use optmisation. It is interesting to observe that the soybean in natura is rich in protein and fat; however, when inserted into the supplement it should not exceed the maximum limit of $5 \%$ of the diet. In the literature there are few studies involving the utilisation of soybean in the formulation of multiple supplements for bovines in grazing (PAULINO et al., 2006).

This study aimed to evaluate the effect of the supply of soybean in natura in substitution for the soybean meal with the nutritional characteristics and the productive of beef heifers for fattening under pasture conditions in Urochloa decumbens, in the dry season. 


\section{Material and Methods}

Place, animals, experimental delineation and supplements

The experiment was conducted in the dependencies of the cattle sector, Department of Zootechnics, Universidade Federal de Viçosa, located in the city of Viçosa-MG $\left(20^{\circ} 45^{\prime} \mathrm{S}\right.$ e $42^{\circ} 52^{\prime}$ W), between the months of July and September 2011, which is the dry season.

During the experimental months the climate data presented a maximum and minimum of 5,3 and $0 \mathrm{~mm} /$ month of rainfall, and 19,6 and $15,9{ }^{\circ} \mathrm{C}$ temperature, respectively (Figure 1).

Figure 1. Precipitation in millimetres $(\mathrm{mm})$ and average temperature in ${ }^{\circ} \mathrm{C}$ during the experiment

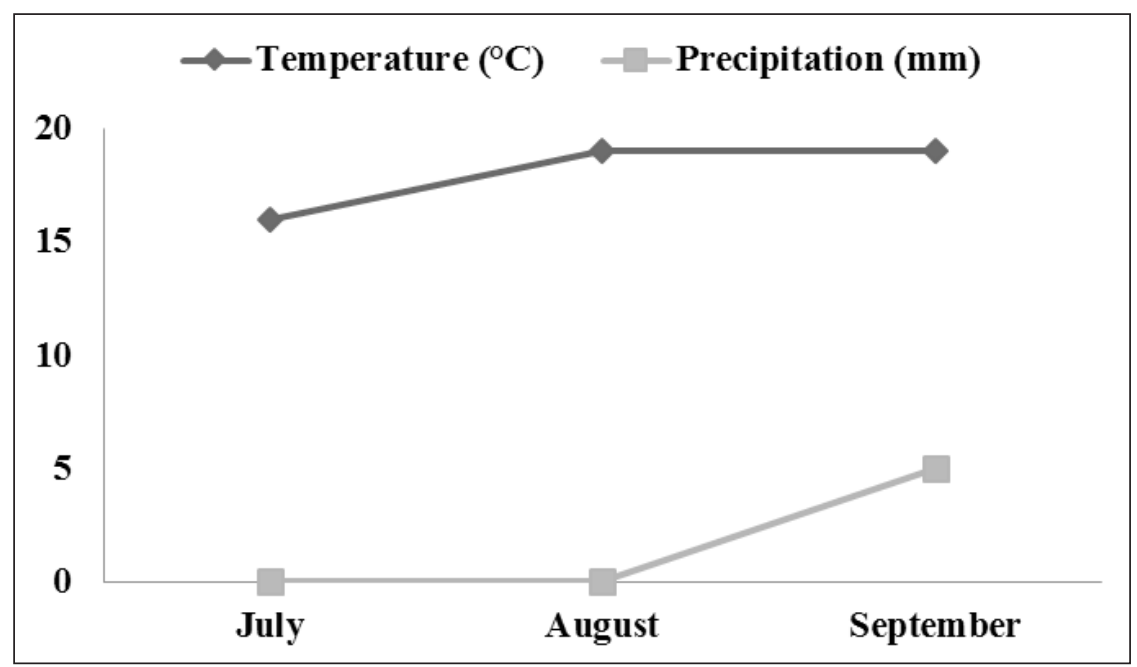

Thirty-nine heifers were used for the evaluation of the productive performance with average initial ages and weights of 21 months and $309.5 \pm 7 \mathrm{~kg}$, respectively.

An experimental area of 12,5 hectares was designated for the animals of productive performance, with five dry lots of 2,5 ha, uniformly covered with Urochloa decumbens grass, and with troughs that were covered, and with access on both sides. The dry lots were deferred in the second half of March and $50 \mathrm{~kg}$ of $\mathrm{N} \mathrm{ha}^{-1}$ were used.

The delineation used was entirely randomised with five treatments and eight repetitions; the control of treatment had seven repetitions. Four supplements were used: two with the protein source being the soybean meal one with $250 \mathrm{~g}$ of PBanimal $^{-}$ ${ }^{1} \mathrm{~kg}^{-1}\left(\mathrm{~F}_{25}\right)$ while the other $400 \mathrm{~g}$ of PB animal ${ }^{-1} \mathrm{~kg}^{-}$ ${ }^{1}\left(\mathrm{~F}_{40}\right)$ of crude protein $(\mathrm{CP})$; and two others using the soybean in natura as the protein source of the same model one containing $250 \mathrm{~g}$ of PB animal ${ }^{-1} \mathrm{~kg}^{-}$ ${ }^{1}\left(G_{25}\right)$ and the other $400 \mathrm{~g}$ of PB animal ${ }^{-1} \mathrm{~kg}^{-1}\left(\mathrm{G}_{40}\right)$, being the total $\mathrm{CP}$ derived from all the ingredients of the supplements. The fifth treatment was the control group and received just mineral salt ad libitum (Table 1). The supplements, whose chemical composition is presented in Table 2, were supplied according to the amount of $1 \mathrm{~kg} \mathrm{dia}^{-1}$ by animal. 
Table 1. Percentual composition of the supplements based on the natural material.

\begin{tabular}{|c|c|c|c|c|}
\hline \multicolumn{5}{|c|}{ Multiple Supplements } \\
\hline Ingredients $(\%)$ & $\mathrm{F} 25$ & G25 & F40 & G40 \\
\hline Ground Corn Kernel & 31,4 & 28,4 & 17,5 & 11,6 \\
\hline Ground Sorghum Grain & 31,4 & 28,4 & 17,5 & 11,6 \\
\hline Soybean Meal & 28,9 & - & 55,1 & - \\
\hline Soybean & - & 34,6 & - & 65,8 \\
\hline Urea SA ${ }^{-1}(9: 1)$ & 2,4 & 2,6 & 4,6 & 5,0 \\
\hline Mineral Blend ${ }^{\mathbf{1}}$ & 6,0 & 6,0 & 6,0 & 6,0 \\
\hline
\end{tabular}

${ }^{1}$ Percentual composition: dicalcium phosphate, 50,00; sodium chloride, 47,15; zinc sulphate, 1,50; copper sulphate, 0,75 ; cobalto sulphate, 0,05; potassium iodide, 0,05 and magnesium sulphate: 0,05 .

Table 2. Chemical composition of the supplements and of the forage.

\begin{tabular}{lccccccc}
\hline \multirow{2}{*}{ Item $^{1}$} & \multicolumn{9}{c}{ Supplements } & \multicolumn{3}{c}{ U. decumbens $^{5}$} \\
\cline { 2 - 7 } & F25 & G25 & F40 & G40 & Period 1 & Period 2 $^{6}$ & Period 3 \\
\hline $\mathrm{DM}^{4}$ & 90,96 & 90,95 & 91,86 & 91,37 & 37,12 & 42,22 & 45,65 \\
$\mathrm{OM}^{2}$ & 91,06 & 91,24 & 89,77 & 90,12 & 92,56 & 93,19 & 94,3 \\
$\mathrm{CP}^{2}$ & 24,45 & 24,3 & 39,3 & 39,0 & 8,10 & 5,04 & 4,57 \\
INMD $^{3}$ & 26,2 & 27,1 & 26,8 & 27,3 & 39,7 & 41,2 & 46,5 \\
$\mathrm{EE}^{2}$ & 1,30 & 7,75 & 1,24 & 13,50 & 1,09 & 1,12 & 1,04 \\
FMDcp $^{2}$ & 21,84 & 21,96 & 21,14 & 21,26 & 65,80 & 71,27 & 74,25 \\
NFC $^{2}$ & 43,89 & 37,45 & 26,31 & 14,18 & 17,57 & 15,76 & 14,44 \\
FMDi $^{2}$ & 1,12 & 1,25 & 0,88 & 1,13 & 23,34 & 27,48 & 30,77 \\
\hline
\end{tabular}

${ }^{1} \mathrm{DM}$ - dry matter; OM - organic matter; CP - crude protein; INMD - insoluble nitrogen in mild detergent; EE - ethereal extract; FMcp - fiber in mild detergent corrected for ashes and protein; NFC - non-fibrous carbohydrates; FMDi - fiber in mild indigestible detergent. ${ }^{2}$ In \% of DM. ${ }^{3}$ In \% of total nitrogen. ${ }^{4}$ In \% of natural material. ${ }^{5}$ Samples obtained by manual simulation of grazing. ${ }^{6}$ Samples collected during the digestibility test.

The urea $\mathrm{SA}^{-1}$ was used to correct the difference of crude protein (CP) between the supplements of bran and soymeal. The animals were weighed at the beginning of the experiment after fasting from solids (pasture and supplement) for 14 hours by the morning. The treatments were randomly designated to the experimental units (animals). It was formed five areas gathering the animals that received the same treatment.

The supplements were supplied daily at 10:00 in the group feeder to allow access to the animals at the same time.

Before the beginning of the experiment, all the animals were submitted to the control of ectoparasites and endoparasites, and during the experimental period when necessary.

Every seven days the animals were rotated between the dry lots aiming to eliminate possible effects on the treatments (availability of pasture, location of the water and trough, relief, shadowing, etc.); the supplement designed to each group of animals in the beginning of the experiment and accompanied when the change of dry lots took place.

Weightings were every 28 days to accompany the performance of the animals; however, the average daily gain of the heifers was estimated by the difference between the final weight and the initial 
weight, both taken after the fasting from solids for 14 hours divided by the number of experimental days (84 days).

\section{Experimental procedures and sample}

The sample to the qualitative evaluation of the pasture consumed by the animals was obtained by manual simulation of grazing. This sample was weighed and taken immediately to the greenhouse with forced circulation of air at $60{ }^{\circ} \mathrm{C}$ for 72 hours and milled in a cutting mill ( 1 and $2 \mathrm{~mm}$ ).

To evaluate the forage, there was fractionation of the experiment in three periods of 28 days. On the fourteenth day of each experimental period, the pasture was collected to determine the total availability of dry matter ha ${ }^{-1}$ through a cut in the soil level in four areas limited by a metalic square of $0,5 \times 0,5 \mathrm{~m}$, selected randomly in each dry lot for future evaluation of the total availability of digestible dry matter (DMpd ha-1). This sample was weighed and then taken immediately to the greenhouse with forced air circulation at $60{ }^{\circ} \mathrm{C}$ for 72 hours.

The DMpd was estimated according to Paulino et al. (2008):

$$
\mathrm{DMpd}=0,98(100-\mathrm{FMD})+(\mathrm{FMD}-\mathrm{FMDi}) .
$$

In which: 0,98: Coefficient of digestibility of the cellular content

DMpd: Dry matter potentially digestible

FMDcp: Fiber in mild detergent corrected for ash and protein

FMDi: Fiber in mild indigestible detergent

The test of digestibility started after 42 days from the beginning of the experiment with a duration of 9 days. The method used has three indicators. To estimate the faecal contamination the external indicator chromic oxide was supplied, coiled in paper sleeves corresponding to $15 \mathrm{~g}$ by animal day ${ }^{-1}$, applied with the help of a metalic probe by esophagus at 9:00. To estimate the individual consumption of the supplement, titanium dioxide $\left(\mathrm{TiO}_{2}\right)$ was used, supplied by supplement in the proportion of $10 \mathrm{~g}$ of indicator $\mathrm{kg}^{-1}$ of animal

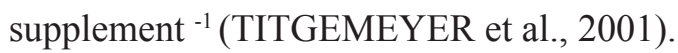

To estimate the consumption of DM of pasture, the FMDi was used as the internal indicator (DETMANN et al., 2001). Six of the nine days of the experiment were destinated to adaptation of the animals to the $\mathrm{Cr}_{2} \mathrm{O}_{3}$ and the $\mathrm{TiO}_{2}$. In the last three days, excrement was collected at three different times of the day: 15:00, 11:00 and 7:00. The samples of feces were collected immediately after defecation or directly in the rectum of the animals in quantities of approximately $200 \mathrm{~g}$, identified by animal, and dried in the greenhouse with forced air circulation ( $60{ }^{\circ} \mathrm{C}$ for 72 hours). Afterwards, they were milled in a cutting mill ( 1 and $2 \mathrm{~mm})$.

On the fifth day of the experiment, to evaluate the nutritional parameters, a simulation of manual grazing took place in each dry lot separately and this sample was used for future evaluation of the consumption and digestibility of the pasture.

On the last day of the digestive experiment "spot" samples of urine were obtained during spontaneous urination and samples of blood through a puncture of the jugular vein were taken four hours after supplying the supplement. After the collection, the samples of urine were diluted in $\mathrm{H}_{2} \mathrm{SO}_{4}(0,036$ $\mathrm{N})$ and frozen at $-20{ }^{\circ} \mathrm{C}$ for future evaluation of the creatinine content, urine and derivatives of purine. The samples of blood were collected at the end of the period of urine collection using a vacuum tube activating blood clots, and separating gel (BD Vacuntainer $^{\circledR}$, SST II Advance). The blood was immediately centrifuged at $2700 \times \mathrm{g}$ for 15 minutes and the serum stored at $-20^{\circ} \mathrm{C}$.

\section{Chemical analysis}

The contents of dry matter (DM), crude protein $(\mathrm{CP})$, mineral matter $(\mathrm{MM})$ and ethereal extract 
(EE), were obtained and determinated through manual simulation of grazing in the samples of forage and in the concentrated food according to Silva and Queiroz (2002); fiber in mild detergent (FMD) according to Mertens (2002), corrected for ash and protein; fiber in indigestible mild detergent (FMDi), obtained after the incubation of bags of Ankon ${ }^{\circledR}$ (F57) in situ for 288 hours, according to Valente et al. (2011); insoluble protein in mild detergent (IPMD), according to the description of Licitra et al. (1996).

Due to the presence of urea in the supplments, the quantification of the non-fibrous carbohydrates (NFC) was made according to Detmann and Valadares Filho (2010):

$\mathrm{NFC}=100-[(\% \mathrm{CP}-\% \mathrm{CP}$ da uréia $+\%$ de uréia $)$ $+\%$ FMDcp $+\%$ EE $+\%$ MM]

Where: FMDcp = fiber in mild detergent corrected for ash and protein

An analysis was made to quantify the content of DM, FMDcp and FMDi and of potentially disgestible dry (DMpd) in the samples of forage.

A sample was taken, composed of feces after drying in the greenhouse with forced air circulation at $60{ }^{\circ} \mathrm{C}$ for each animal the three days of collection. The samples were kept in identified plastic pots and subsequently analysed with respect to the content of chrome through atomic absortion spectophotometry as described by Willians et al. (1962); titanium dioxide by calorimetry (SHORT; ADAMS, 1988), following the recommendations of Detmann et al. (2012), as well as the contents of DM, CP, EE, FNDcp, FMDi and ash, as described previously.

The excretion of dry faecal matter was estimated using the indicator chromic oxide, with the estimation based on a rate between the quantity of the provided indicator and its concentration in the feces.

The estimate of individual consumption of multiple supplements by the heifers was obtained through the following equation:

$$
\text { CISup }=\left((E F x C I F i) I F G^{-1}\right) \times \operatorname{SupFG}
$$

Where: ICSup $=$ individual consumption of supplement $\left(\mathrm{kg}\right.$ animal ${ }^{-1}$ day $\left.^{-1}\right) ; \mathrm{FE}=$ faecal excretion in $\mathrm{kg}$ animal ${ }^{-1} \mathrm{day}^{-1} ; \mathrm{CIFi}=$ concentration of the indicator in the feces of the $\left(\mathrm{kg} \mathrm{kg}^{-1}\right)$; ISG $=$ indicator present in the supplement supplied to the group $\left(\mathrm{kg} \mathrm{day}^{-1}\right)$; SupSG = quantity of supplement supplied to the group of animals $\left(\mathrm{kg}^{\mathrm{day}}{ }^{-1}\right)$. The estimate of volunteer consumption of dry matter of forage was made using the indigestible FMD as the internal indicator, according to the following equation:

\section{$\mathrm{CDM}\left(\mathrm{kg} \mathrm{day}^{-1}\right)=\left\{[(\mathrm{FExCIF})-\mathrm{IS}] \mathrm{CIFO}^{-1}\right\}+$ CDDM}

Wherein CIF = concentration of the indicator in the feces $\left(\mathrm{kg} \mathrm{kg}^{-1}\right)$; CIFO = concentration of the indication in the forage $\left(\mathrm{kg} \mathrm{kg}^{-1}\right)$; CDDM $=$ consumption of dry matter of supplement ( $\mathrm{kg}$ day $\left.{ }^{1}\right) ; \mathrm{FE}=$ faecal excretion $\left(\mathrm{kg}\right.$ animal $\left.{ }^{-1} \mathrm{day}^{-1}\right)$; and IS = consumption of indicator from the supplement $(\mathrm{kg})$.

The analysis of creatinine, uric acid and urea was made with the automatic equipment of the biochemistry label Mindray model: BS200E, using determination kits of Bioclin.

The methodology for the determination of uric acid was the enzimatyc calorimetric through the utilisation of an enzymatic reagent containing: buffer solution, 4-aminoantipyrine, sodium azide, peroxidase and uricase. The intensity of the cherry colour formed in the chromogen is directly proportional to the concentration of uric acid in the sample that was measured in the wavelength 505 $\mathrm{nm}(490-540 \mathrm{~nm})$.

The method for the quantification of urea was the cinetic with a fixed time. Firstly, the urea is hydrolysed in amonia and carbon dioxide by urease, then the glutamate deshydrogenase in the presence of amonia and $\alpha$-cetoglutarato oxides, NADH the $\mathrm{NAD}+$. The oxidation of NADH to NAD + , measured through the diminishing absorbance is proportional 
to the concentration of urea in the sample that was read spectophotometrically between 334 and 365 nm.

The quantification of the creatinine was made with the cinetic calorimetric methodology where the creatinine reacts with the alkaline picrate in a tamponade media obtaining a chromogen whose absorbance is proportional to the concentration of creatinine in the sample measured in the wavelength $510 \mathrm{~nm}$. The non-specific chromogens were eliminated by a pre-reading because they had an immediate formation. The determination of urinary daily was done using the relation between the daily excretion of creatinine, adopting the equation proposed by Silva et al. (2012) and its concentration in the "spot" samples.

$$
\operatorname{ECU}\left(\mathrm{g} \mathrm{day}^{-1}\right)=0,0345 \times \mathrm{PCJ}^{0,9491}
$$

Where: $\mathrm{CWF}=$ corporal weight in fasting.

The analysis of allantoin was done with calorimetric (CHEN; GOMES, 1992). The total excretion of derivatives of purines was calculated by the sum of the quantities of allantoin and uric acid excreted in the urin.

The absorbed purines (Y, mmolday ${ }^{-1}$ ) were calculated from the excretion of derivatives of purines $\left(\mathrm{X}, \mathrm{mmoldia}^{-1}\right)$ with the following equation:

$$
P A=\frac{D P-0,301 \times P C^{0,75}}{0,80}
$$

Where: 0,80 is the recovery of absorbed purines, such as derivatives of purines and $0,301 \mathrm{xPC}^{0,75}$, the endogenous contribution to the excretion of purines (BARBOSA et al., 2011).

The ruminal summary of nitrogenous compounds (Y, g Nmicdia ${ }^{-1}$ ) was calculated in function of the absorbed purines (X, mmolday ${ }^{-1}$ ), using the equation described by Barbosa et al. (2011):

$$
N_{\text {mic }}=\frac{70 \times P A}{0,93 \times 0,137 \times 1000}
$$

Where: 70 is the content of $\mathrm{N}$ of purines (mg $\mathrm{N}$ mol $\left.{ }^{-1}\right) ; 0,137$, the ratio $\mathrm{N}$ purines: $\mathrm{N}$ total in the bacterial; and 0,93 , the digestibility of bacterial purines.

\section{Statistical analysis}

The results were subjected to analysis of variance adopting the corporal weight as covariate and even when it was not significant, it was removed from the model. The comparisions between the averages were made through decomposition of the sum squares to treatments in orthogonal contrasts referring to the comparision between supplemented and non-supplemented, the presence of soybean meal or soybean in the supplements and the concentration of crude protein in the supplement, 25 or $40 \%$. The PROC GLM SAS (Statistical Analysis System, version 9.2) was used in all the statistical analyses. For all the statistical procedures $\alpha=0,10$ was adopted.

\section{Results and Discussion}

The average forage supply was $4529,6 \mathrm{~kg} \mathrm{ha}^{-}$ ${ }^{1}$ of DM (Figure 2) that corresponded to $50,5 \mathrm{~g} \mathrm{~kg}^{-1}$ of the corporal weight $(\mathrm{CW})$ and it is in the range of 70 to $110 \mathrm{~g} \mathrm{~kg}^{-1}$ of $\mathrm{CW}$ of the fare of farage to obtain big average daily gain (ADG) without affecting the gain by area too much (BARBOSA et al., 2006). 
Figure 2. Mass of dry matter (DM) and potentially digestible dry matter (DMpd) during the period of tests.

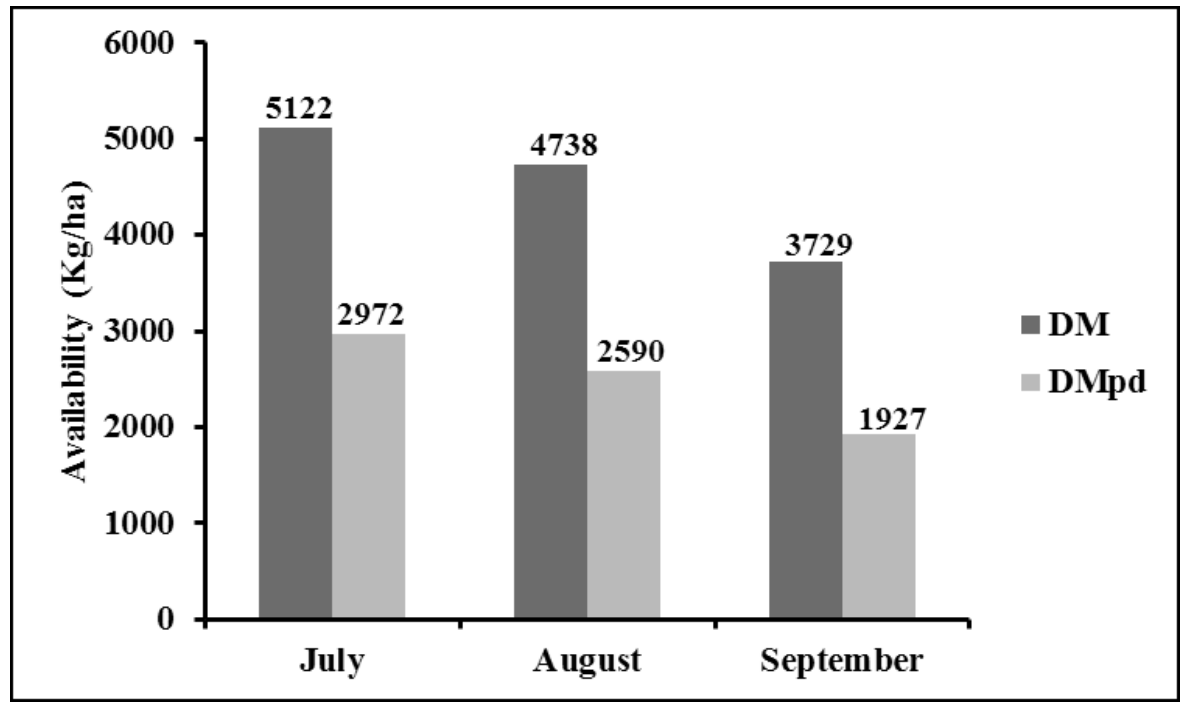

The values of mass of DM and DMsp of the pasture for all the experimental periods (three periods of 28 days each) are presented in Figure 2. The average mass of $2496 \mathrm{~kg} \mathrm{ha}^{-1}$ of $\mathrm{MDpd}$, corresponded to $27,8 \mathrm{~g} \mathrm{~kg}^{-1}$ of the $\mathrm{CW}$; Paulino et al. (2004) recommend 40 to $50 \mathrm{~g} \mathrm{~kg}^{-1}$ of the CW supply of animals from grazing DMpd for satisfatory performance. The percentage of DMpd in relation to DM were 58,$03 ; 54,66$; and 51,67 in July (first period), August (second period) and September (third period), respectively. Since DMpd is the basal resource in the feeding of this system of production, its deficit requires supplementary resources.

The supplemented animals presented an average daily gain (ADG) superior to the ones of the animals of the treatment control $(\mathrm{P}<0,10)$. This larger $\mathrm{ADG}$ corresponded to the greater final corporal weight (FCW) of the supplemented animals $(\mathrm{P}<0,10)$ (Table 3).

Table 3. Averages, coefficients of variation and significance indicatives for initial corporal weight (ICW), final corporal weight $(\mathrm{FCW})$ and average daily gain $(\mathrm{ADG})$ for the different treatments.

\begin{tabular}{cccccccccc}
\hline \multirow{2}{*}{ Item } & \multicolumn{4}{c}{ Supplements } & \multirow{2}{*}{ CV $(\%)$} & \multicolumn{3}{c}{ Contrasts (Value - P) ${ }^{1}$} \\
\cline { 2 - 4 } \cline { 9 - 10 } & MM & F25 & G25 & F40 & G40 & & MM x SUP & 25 x 40 & Bran x Grain \\
\hline ICW $^{2}$ & 309,3 & 309,1 & 309,7 & 309,3 & 309,9 & --- & -- & -- & --- \\
FCW $^{2}$ & 323,0 & 340,1 & 340,2 & 346,1 & 341,9 & 2,95 & 0,001 & 0,304 & 0,454 \\
ADG $^{2}$ & 0,154 & 0,348 & 0,343 & 0,414 & 0,360 & 33,78 & 0,001 & 0,298 & 0,446 \\
\hline
\end{tabular}

${ }^{1}$ Significance indicatives for the contrast between supplemented animals and non-supplemented (MM x SUP), contrast between animals that received 25 and $40 \%$ of CP in the supplement $(25 \mathrm{x} 40)$, contrast between animals that received supplement with soybean meal and with soybean (bran $\mathrm{x}$ grain). ${ }^{2}$ in $\mathrm{kg}$.

The performance of the supplemented animals independently of the content of CW or ingredients used was nearly $138 \%$ higher than the one of the heifers that received just a mineral mix. There was no difference in $\mathrm{ADG}$ and $\mathrm{FCW}$ that was higher than the one of the heifers that received just mineral mix. There was no difference of AGD and FCW between the supplemented treatment F25, G25, F40 e G40 
$(\mathrm{P}>0,10)$. The total substitution of soybean meal for soybean did not lead to a change in the performance.

The Urochloa decumbens obtained through the manual simulation of grazing presented an average content of $5,90 \%$ of $\mathrm{CP}$ in the DM of the forage, and it is under the minimum value of $7-8 \%$ of $\mathrm{CP}$ on the basal diet, explaining the lower perfomance of animals receiving only the mineral.

In the beginning of the experiment, the greater availability of forage with better nutritional value and an average content of $8,10 \%$ of $\mathrm{CP}$, was decisive so that the treatment obtained expressive compensatory gain resulting in a considerable GMD of $0,154 \mathrm{~kg}$ at the end of the experiment.

The forage presented during the whole experiment averaged $42,47 \%$ of protein in the form of insoluble nitrogen in mild detergent (INMD); in other words, it was slowly available to the animal, which justifies the utilisation of protein supplements.

The average content of FMDi was $27,2 \%$, which has been attributed to the effect of ruminal repletion of tropical forage (VIEIRA et al., 1997), causing a decrease in the consumption. The biggest consumption of dry matter is associated with the best perfomance, which confirms the positive effect of supplementing $(\mathrm{P}<0,10)$ on the consumption of DM, MO, CP, FMDcp, NDT in kg day ${ }^{-1}$ and DM, FMDcp in $\mathrm{g} \mathrm{kg}^{-1}$ of the CP (Table 4). Although the consumption of DMP was similar to $\mathrm{P}>0,10$ between all the treatments, in fact, the difference in the ingestion of DM observed refers to an additive effect proportional to the ingested supplements. Furthermore, a difference was found bewteen the DM effectively digested (MDd) and the treatment control and the supplements, which reinforces the best performance of the latter. The consumption of total DM in relation to the corporal weight was $1,63 \%$ for the animals of the treatment control, and $2,09 \%$ of the supplemented animals. The supplments with soybean elevated the level of EE in the total diet to $1,03 \%$ (treatments with soybean meal and control to 2,04\% of EE (G 25) and 2,58\% of EE ( $\mathrm{G} 40$ ); however, it did not lead to animal gain and consumption of NDT.

Table 4. Averages, coefficients of variation and significance indicatives of the voluntary consumption in grazing heifers receiving supplements and not receiving supplements.

\begin{tabular}{|c|c|c|c|c|c|c|c|c|c|}
\hline \multirow{2}{*}{ Item } & \multicolumn{5}{|c|}{ Supplements } & \multirow{2}{*}{$\mathrm{CV}(\%)$} & \multicolumn{3}{|c|}{ Contrasts (Value - P) ${ }^{1}$} \\
\hline & MM & $\mathrm{F} 25$ & G25 & $\mathrm{F} 40$ & G40 & & MM x Sup & $25 \times 40$ & Bran x Grain \\
\hline Dry Matter & 5,46 & 7,11 & 7,30 & 6,94 & 7,31 & 17,83 & 0,001 & 0,857 & 0,593 \\
\hline Dry Matter of Forage & 5,46 & 6,23 & 6,41 & 6,05 & 6,42 & 19,09 & 0,106 & 0,836 & 0,520 \\
\hline Organic Matter & 5,11 & 6,74 & 6,82 & 6,53 & 6,82 & 18,97 & 0,001 & 0,815 & 0,579 \\
\hline Organic Matter Forage & 5,11 & 5,77 & 5,96 & 5,72 & 5,98 & 18,86 & 0,110 & 0,834 & 0,493 \\
\hline Crude Protein & 0,26 & 0,52 & 0,49 & 0,62 & 0,67 & 16,81 & 0,001 & 0,001 & 0,842 \\
\hline FMDcp $^{2}$ & 3,96 & 4,88 & 4,98 & 4,79 & 4,85 & 18,66 & 0,017 & 0,718 & 0,812 \\
\hline Digested Dry Matter & 2,95 & 3,84 & 3,85 & 3,66 & 3,82 & 18,46 & 0,009 & 0,661 & 0,737 \\
\hline FMDD $^{2}$ & 2,38 & 2,91 & 2,93 & 2,74 & 2,72 & 18,90 & 0,098 & 0,303 & 0,951 \\
\hline Total Digestible Nutrients & 2,95 & 3,79 & 3,85 & 3,58 & 3,81 & 18,18 & 0,005 & 0,586 & 0,571 \\
\hline \multicolumn{10}{|c|}{$\mathrm{gkg}^{-1}$ of $\mathrm{CW}$} \\
\hline Dry Matter & 16,31 & 20,99 & 21,11 & 20,02 & 21,12 & 17,18 & 0,003 & 0,697 & 0,616 \\
\hline Dry Matter of Forage & 16,31 & 18,15 & 18,42 & 17,24 & 18,41 & 18,28 & 0,206 & 0,691 & 0,535 \\
\hline FMDcp $^{2}$ & 11,81 & 14,23 & 14,31 & 13,65 & 13,91 & 17,92 & 0,036 & 0,572 & 0,844 \\
\hline
\end{tabular}

${ }^{1}$ Significance indicatives for the contrast between supplemented animals and non-supplemented (MM x SUP), contrast between animals that received 25 and $40 \%$ of CP in the supplement $(25 \times 40)$, contrast between animals that received supplement with soybean meal and with soybean (Bran x Grain). ${ }^{2}$ in $\mathrm{kg}$.

${ }^{2}$ FMDcp: Fiber in mild detergent corrected for ashes and protein. FMDD: Fiber in mild digestible detergent. 
The difference in consumption of $\mathrm{CP}$ occurred by the increase in the supply of multiple supplments; this was the biggest source of this nutrient in relation to the pasture. The greatest ingestion of NDT was due to, mainly, the greater digestibility of total MD and its constituents. There was also an effect from the supplementation $(\mathrm{P}<0,10)$ on the coefficients of digestibility of MD, MO, CP, FMDcp, NDT (Table 5).

Table 5. Averages, coefficients of variation and significance indicatives for the total apparent digestibility coefficients $(\%)$ of the components of the diet to supplemented and non-supplemented heifers.

\begin{tabular}{lccccccccc}
\hline \multirow{2}{*}{ Item $^{1}$} & \multicolumn{5}{c}{ Treatments } & \multirow{2}{*}{ CV(\%) } & \multicolumn{3}{c}{ Contrasts (Value - P) $^{2}$} \\
\cline { 2 - 3 } & MM & F25 & G25 & F40 & G40 & & MM x Sup & $25 \times 40$ & Bran x Grain \\
\hline DM & 50,68 & 53,25 & 52,22 & 52,24 & 51,97 & 3,73 & 0,009 & 0,372 & 0,348 \\
OM & 53,26 & 56,05 & 55,16 & 54,86 & 54,33 & 5,75 & 0,008 & 0,356 & 0,298 \\
CP & 25,26 & 44,25 & 31,19 & 47,23 & 42,53 & 21,45 & 0,001 & 0,019 & 0,004 \\
FMDcp & 55,30 & 59,84 & 58,72 & 57,49 & 56,02 & 3,47 & 0,001 & 0,001 & 0,082 \\
TDN & 50,63 & 52,70 & 52,20 & 51,15 & 51,78 & 3,87 & 0,054 & 0,175 & 0,945 \\
\hline
\end{tabular}

${ }^{1}$ DM - dry matter; OM - organic matter; CP - crude protein; FMDcp - fiber in mild detergent corrected for ash and protein; TDN - total digestible nutrients. ${ }^{2}$ Significance indicatives to the contrast between supplement and non-supplemented animals (MM $\mathrm{x}$ SUP), contrast between animals that received 25 and $40 \%$ of CP in the supplement $(25 \mathrm{x} 40)$ and contrast between animals that received supplement with soybean meal and soybean (Bran x Grain).

The digestibility of $\mathrm{CP}$ of the supplemented animals was superior to that of the mineral treatment due to the bigger concentration of this components in the supplments, which increases its role in the total diet, reducing the participation of the faecal metabolic (VAN SOEST, 1994).
There was an effect of the supplementation $(\mathrm{P}<0,10)$ on the flow of microbial nitrogenous compounds (Nmic-g day ${ }^{-1}$ ) and efficiency of microbial synthesis (Emic) expressed in $\mathrm{g}$ of PBmickg ${ }^{-1}$ NDT consumed (Table 6).

Table 6. Averages and standard deviation of the production of microbial nitrogen (Nmic), microbial efficient in relation to the total digestible nutrients (Emic), urea nitrogen in the plasma (NUS) and urea nitrogen in the urine/nitrogen of creatinine (NU/NC) to the suplemented and non-supplemented heifers.

\begin{tabular}{|c|c|c|c|c|c|c|c|c|c|}
\hline \multirow{2}{*}{ Item } & \multicolumn{5}{|c|}{ Supplements } & \multirow{2}{*}{ CV $(\%)$} & \multicolumn{3}{|c|}{ Contrasts (Value - P) ${ }^{1}$} \\
\hline & MM & F 25 & G 25 & F 40 & G 40 & & MM x SUP & $25 \times 40$ & Bran x Grain \\
\hline $\mathrm{Nmic}^{2}$ & 53,11 & 64,57 & 63,52 & 56,26 & 55,27 & 12,60 & 0,034 & 0,006 & 0,721 \\
\hline $\mathrm{Emic}^{3}$ & 120,44 & 108,45 & 110,88 & 97,40 & 91,13 & 15,70 & 0,010 & 0,013 & 0,739 \\
\hline $\mathrm{NUS}^{4}$ & 7,40 & 16,00 & 15,60 & 18,40 & 22,20 & 13,75 & 0,001 & 0,001 & 0,041 \\
\hline $\mathrm{NU} / \mathrm{NC}$ & 3,33 & 12,37 & 15,16 & 16,20 & 18,91 & 21,54 & 0,001 & 0,001 & 0,014 \\
\hline
\end{tabular}

${ }^{1}$ Significance indicatives for the contrast between supplemented animals and non-supplemented (MM x SUP), contrast between animals that received 25 and $40 \%$ of CP in the supplement $(25 \mathrm{x} 40)$, contrast between animals that received supplement with soybean meal and with soybean (Bran x Grain). ${ }^{3}$ in $\mathrm{kg}$. in $\mathrm{g} \mathrm{CP}$ microbial $\mathrm{Kg}^{-1}$ of total digestible nutrients. ${ }^{4}$ in $\mathrm{mg} \mathrm{dL}^{-1}$ of serum.

The supplementation elevated the availability of nitrogen and readily available energy to microbial assimilation, and this led to an increase in the flow of Nmic in the supplemented animals in the order of $12,8 \%$ in comparision to the control animals. 
The estimated Emic of $120 \mathrm{~g}$ of $\mathrm{P} \mathrm{kg}^{-1}$ of NDT to the treatment control was equal to the theorical value sugested by Valadares Filho et al. (2010) in tropical conditions.

The supplementation increased $(\mathrm{P}<0,10)$ the levels of ureic nitrogen in the serum (UNS). There was a difference in the levels of UNS between the animals that received soybean meal and soybean, which can be explained by the higher concentration of urea in the supplement containing grain. The supplementation caused a greater $(\mathrm{P}<0,10)$ excretion of ureic nitrogen (UN/NC).

\section{Conclusions}

In conclusion, the supply of multiple supplements optimises the performance of grazing heifers in the dry season; and the substitution of the soybean meal to soybean does not change the performance of the animals.

Note: This material was approved by the bioethics committee of Universidade Federal de Viçosa.

\section{Acknowledgments}

We would like to thank the CNPq (Conselho Nacional de Desenvolvimento Científico e Tecnológico) for the funding of this research.

\section{References}

ANUÁRIO DA PECUÁRIA BRASILEIRA ANUALPEC. São Paulo: Instituto FNP, 2007. 368 p.

BARBOSA, A. M.; VALADARES, R. F. D.; VALADARES FILHO, S. C.; PINA, D. S.; DETMANN, E.; LEÃO, M. I. Endogenous fraction and urinary recovery of purine derivatives obtained by different methods in Nellore cattle. Journal of Animal Science, Viçosa, MG, v. 89, n. 2, p. 510-519, 2011.

BARBOSA, M. A. A. F.; NASCIMENTO JÚNIOR, C.; CECATO, U. Dinâmica da pastagem e desempenho de novilhos em pastagem de capim tanzânia sob diferentes ofertas de forragem. Revista Brasileira de Zootecnia, Viçosa, MG, v. 35, n. 4, p. 1594-1600, 2006.

CHEN, X. B.; GOMES, M. J. Estimation of microbial protein supply to sheep and cattle based on urinary excretion of purine derivatives: an overview of the technical details. Ocasional publication. Buchsburnd Aberdeen: Ed. Rowett Research Institute, 1992. 21 p.

DETMANN, E.; PAULINO, M. F.; ZERVOUDAKIS, J. T.; VALADARES FILHO, S. C.; EUCLIDES, R. F.; LANA, R. P.; QUEIRÓZ, D. S. Cromo e indicadores internos na determinação do consumo de novilhos mestiços, suplementados, a pasto. Revista Brasileira de Zootecnia, Viçosa, MG, v. 30, n. 5, p. 1600-1609, 2001.

DETMANN, E.; SOUZA, M. A.; VALADARES FILHO, S. C.; QUEIROZ, A. C.; BERCHIELLI, T. T.; SIMÕES SALIBA, E. O.; CABRAL, L. S.; PINA, D. S.; LADEIRA, M. M.; GOMES, J. A. Métodos para análise de alimentos. Instituto Nacional de Ciência e Tecnologia de Ciência Animal, Viçosa, MG, v. 1, n. 1, p. 2-214, 2012.

DETMANN, E.; VALADARES FILHO, S. C. On the estimation of non-fibrous carbohydrates in feeds and diets. Arquivo Brasileiro de Medicina Veterinária e Zootecnia, Belo Horizonte, MG, v. 62, n. 4, p. 980-984, 2010.

LICITRA, G.; HERNANDEZ, T. M.; VAN SOEST, P. J. Standardization of procedures for nitrogen fractionation of ruminant feeds. Animal Feed Science and Technology, v. 57, p. 347-358, 1996.

MERTENS, D. R. Gravimetric determination of amylasetreated neutral detergent fiber in feeds with refluxing in beaker or crucibles: collaborative study. Journal of AOAC International, v. 85, n. 6, p. 1217-1240, 2002.

PAULINO, M. F.; DETMANN, E.; VALADARES FILHO, S. C. Bovinocultura funcional nos trópicos. In: SIMPÓSIO DE PRODUÇÃO DE GADO DE CORTE, SIMPÓSIO INTERNACIONAL DE PRODUÇÃO DE GADO DE CORTE, 6; 2., 2008, Viçosa, MG. Anais... Viçosa, MG: VI SIMCORTE, 2008. p. 275-305.

PAULINO, M. F.; FIGUEIREDO, D. M.; MORAES, E. H. B. K.; PORTO, M. O.; SALES, M. F. S.; ACEDO, T. S.; VILLELA, S. D. J.; VALADARES FILHO, S. C. Suplementação de bovinos em pastagem: uma visão sistêmica. In: SIMPÓSIO DE PRODUÇÃO DE GADO DE CORTE, 4., 2004, Viçosa, MG. Anais... Viçosa, MG: SIMCORTE, 2004. p. 93-139.

PAULINO, M. F.; ZAMPERLINI, B.; FIGUEIREDO, D. M.; MORAES, E. H. B. K. de; FERNANDES, H. J.; PORTO, M. O.; SALES, M. F. L.; PAIXÃO, M. L.; ACEDO, T. S.; DETMANN, E.; VALADARES FILHO, 
S. C. Bovinocultura de precisão em pastagens. In: SIMPÓSIO DE PRODUÇÃO DE GADO DE CORTE, 5., 2006, Viçosa, MG. Anais... Viçosa, MG: SIMCORTE, 2006. p. 361-412.

SHORT, R. E.; ADAMS, D. C. Nutritional and hormonal interrelationships in beef cattle reproduction. Canadian Journal Animal Science, Ottawa, v. 68, n. 1, p. 29-39, 1988.

SILVA, D. J.; QUEIROZ, A. C. Análise de alimentos: métodos químicos e biológicos. 3. ed. Viçosa, MG: UFV, 2002. $165 \mathrm{p}$.

SILVA, L. F. C.; VALADARES FILHO, S. C.; CHIZZOTTI, M. L. Creatinine excretion and relationship with body weight of Nellore cattle. Revista Brasileira de Zootecnia, Viçosa, MG, v. 41, n. 3, p. 807 810, 2012.

TITGEMEYER; E. C.; ARMENDARIZ, C. K.; BINDEL, D. J.; GREENWOOD, R. H.; LOEST, C. A. Evaluation of titanium dioxide as a digestibility marker for cattle. Journal of Animal Science, Champaign, v. 79, n. 4, p. 1059-1063, 2001.
VALADARES FILHO, S. C.; MARCONDES, M. I.; CHIZZOTTI, M. L. Exigências nutricionais de zebuínos puros e cruzados BR-CORTE. 2. ed. Viçosa, MG: UFV, DZO, 2010. 193 p.

VALENTE, T. N. P.; DETMANN, E.; QUEIROZ, A. C.; VALADARES FILHO, S. de C.; GOMES, D. I.; FIGUEIRAS, J. F. Evaluation of rumen degradation profiles of forages using bags made from different textiles. Revista Brasileira de Zootecnia, Viçosa, MG, v. 40, n. 11, p. 2565-2573, 2011.

VAN SOEST, P. J. Nutritional ecology of the ruminant. $2^{\text {th }}$ ed. Ithaca: Cornell University Press, 1994. 476 p.

VIEIRA, R. A. M.; PEREIRA, J. C.; MALAFAIA, P. A. M. Fracionamento e genética de degradação in vitro dos compostos nitrogenados da extrusa de bovinos a pasto. Revista Brasileira de Zootecnia, Viçosa, MG, v. 29, n. 3, p. 880-888, 1997.

WILLIANS, C. H.; DAVID, D. J.; IISMA, O. The determination of chromic oxide in faces samples by atomic absorption spectrophotometry. Journal of Agricultural Science, Cambridge, v. 59, n. 3, p. 381-385, 1962. 